\title{
Hydrochemistry of the Mixed Dead Sea-Red Sea Water under Different Impoundment Scenarios as a Time Dependent State
}

\author{
J. Abu-Qubu', O. Rimawi ${ }^{2 *}$, A. Anbar ${ }^{2 *}$, T. Alebous ${ }^{3}$, Z. S. H. Abu-Hamatteh ${ }^{4}$ \\ ${ }^{1}$ Ministry of Energy and Mineral Resources, Amman, Jordan \\ ${ }^{2}$ The University of Jordan, Amman, Jordan \\ ${ }^{3}$ The World Islamic and Science University, Amman, Jordan \\ ${ }^{4}$ Civil Engineering Department, Faculty of Engineering Technology, Al-Balqa Applied University, Amman, Jordan \\ Email: *rimawiom@ju.edu.jo, *a.anbar@ju.edu.jo
}

How to cite this paper: Abu-Qubu, J., Rimawi, O., Anbar, A., Alebous, T., \& AbuHamatteh, Z. S. H. (2022). Hydrochemistry of the Mixed Dead Sea-Red Sea Water under Different Impoundment Scenarios as a Time Dependent State. Journal of Geoscience and Environment Protection, 10, 94-108. https://doi.org/10.4236/gep.2022.101007

Received: September 29, 2021

Accepted: January 14, 2022

Published: January 17, 2022

Copyright $\odot 2022$ by author(s) and Scientific Research Publishing Inc. This work is licensed under the Creative Commons Attribution International License (CC BY 4.0).

http://creativecommons.org/licenses/by/4.0/

\section{(c) (i) Open Access}

\begin{abstract}
The expected water mixing process between Red/Dead Sea water during the proposed conveyance projects is the main target of this research. The project will ensue transporting Red Sea water to recover and maintain certain level of the Dead Sea, mostly will reach $-395 \mathrm{~m}$. It is found that, the two different water bodies with different EC values or different densities (salinities) are relatively divided by stable plane. This plane is defined as the BARZACH PLANE. In this study, the mixing process occurred between the Red Sea with the Dead Sea waters, located at $20 \%-24 \%$ of the Dead Sea column depth based on the Barzach Plane level. During a laboratory experimental work, it is found that the mixed Red/Dead Sea water evaporates in a high rate until certain level where the solution attains oversaturated conditions with different dissolved solids. At this stage, a thin layer of solids suddenly formed and floated at the surface of the dense brine. The salinity of the captured water is so dense that floated salt layer cannot be dissolved. In addition, the formed floated salt layer at the surface prevents the below captured water to evaporate and at this stage, stalactites start to form until the excess dissolved solids are not oversaturated with any mineral.
\end{abstract}

\section{Keywords}

Hydrochemistry, Dead Sea, Red Sea, Brine Water, Mixing Process, Barzach Plan, Jordan

\section{Introduction}

The sever drawdown of the Dead Sea water level is due to successive barriers of 
the inflow water resources. The serious need to save the drying Dead Sea by new perennial source therefore emerged to prevent an important environmental catastrophe on the Dead Sea and its vicinity (Figure 1).

The main tributary of the Dead Sea is the Jordan River, which was supplying about two billion cubic meters in 1930s, dropped to about 1100 million cubic meters in 1950s. However, a dramatically drop to about 340 million cubic meters was recorded during the last few years. Therefore, the estimated 2013 annual water balance of the Dead Sea revealed a shortage of about one billion cubic meter to stabilize the water loss of the Dead Sea (WAJ, 2014; Meteorological Department, 2002). This is attributed to the intensive evaporation rates, increasing demand of the industrial work, the large shortage in surface water resources by increasing dammed runoff waters and the turning of the inflow water to other uses such as the Israeli turning channels and King Abdullah Canal (Abu-Qubu et al., 2016).

According to the given storage in the side wadi reservoirs by the Jordan Water Authority claimed that about 105 million cubic meters were captured in dams constructed on the side wadis of the Jordan River (MWI, 2015; Margane et al., 2002). On the other hand, the increased industrial uses of the Dead Sea water to produce potash and the other relevant industrial minerals consumed about 256

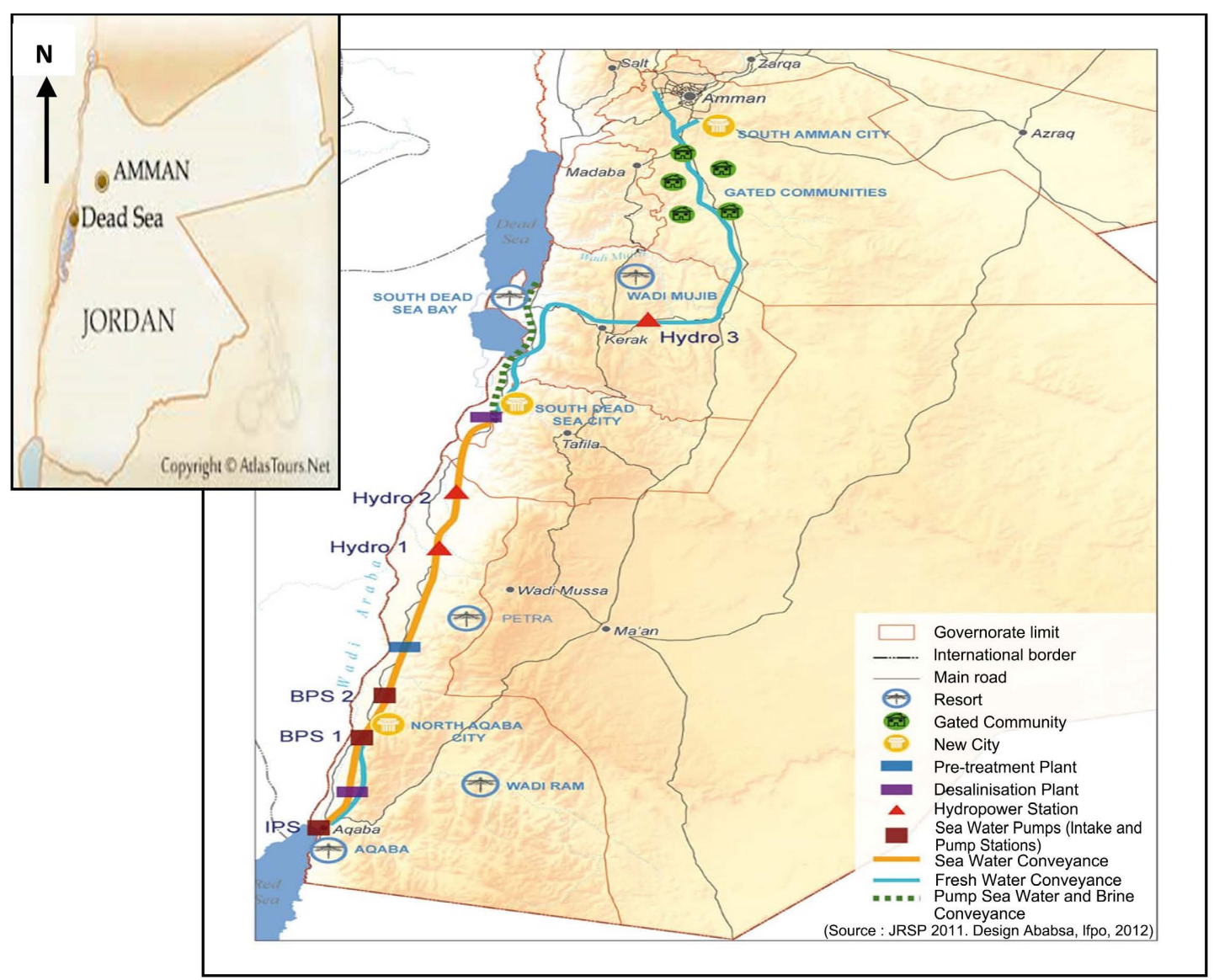

Figure 1. Study area showing the Red/Dead Sea route. 
million cubic meters per year. All these factors are integrated to cause a deficit in the Dead Sea water balance. The Dead Sea water balance indicates that the input is about $310 \mathrm{MCM}$ whereas, the output is about $985 \mathrm{MCM}$ highlighting that the annual loss of water in the Dead Sea is approximately -700 MCM (Abu-Qubu et al., 2016).

Such sever conditions advocate intervention of the surrounding countries to find the Red/Dead Sea conveyance through the proposed World Bank Project (The World Bank, 2009) as an attempt to overcome this problem. Three main scenarios were suggested by the World Bank to execute the conveyance project: i.e., 1) the conveyance capable to supply one billion cubic meters per year; 2) the conveyance capable to supply one and half billion cubic meters per year and 3) the conveyance capable to supply two billion cubic meters per year. The difference in the chemical composition of the transformed Red Sea water to the Dead Sea will lead to many changes to the Dead Sea hydrochemical characteristics, which is considered as a very unique water. The critical characteristics are the chemical ions ratios, and then the total dissolved solids measurements, EC values, ions concentration and the precipitated salts, in order to study the expected changes that may take place at different conditions as related to time of impoundment. The current investigation examines the possible changes of the Dead Sea water taking into account deals the scenario of the two billion cubic meters of transformed Red Sea water to the Dead Sea (Khlaifat et al., 2020; Reiss et al., 2021).

\section{Dead Sea Inflow Waters}

The available Yarmouk River at Adasiya inflows and the Jordan River at Damya flood gauge stations were manipulated using time series analysis to simulate the historic inflow data over the period 1930 to 2013 (MWI, 2014). The successive ten years' averages of these measurements are given in Table 1 . The outflows represented by the industrial abstractions by both the Arab Potash Company (APC) and The Work Industry Company (WIC), were estimated to consume about $256 \times 106 \mathrm{~m}^{3}$ in addition to the calculated evaporation of about $1600 \times 106$ $\mathrm{m}^{3}$ for the year 2015 (Abu-Qubu et al., 2016; Khlaifat et al., 2020). The values presented in Table 1 show the total runoff coming through the northern catchment area of the Dead Sea. These records revealed consecutive downward trends due to the increased deviation and abstractions in their upper catchments over time. The severe declination occurred since 1960s where the highest value recorded $2125 \times 106 \mathrm{~m}^{3}$ in 1968/1969. On contrary, the lowest record within the year reached $282 \times 106 \mathrm{~m}^{3}$ in 1990/1991.

The return flows to the Dead Sea in the Jordan River Valley (JRV) have been estimated to be about $15 \%$. Other water withdrawals such as in the West Bank and Wadi Araba have been assumed to be taken mainly from groundwater and thus do not affect the surface water balance (MWI, 2013).

Surface water flow records for the wadis on the eastern and western side at the 
Table 1. The DEAD SEA 10-years average surface water inflows from the Jordan River $\left(106 \mathrm{~m}^{3}\right)$.

\begin{tabular}{cccccccccccccc}
\hline Year & Oct. & Nov. & Dec. & Jan. & Feb. & Mar. & Apr. & May & Jun. & Jul. & Aug. & Sep. & Total \\
\hline $1928 / 29$ & 38.5 & 50.5 & 88.8 & 160.1 & 554.5 & 390.7 & 273.3 & 200.8 & 115.5 & 71.3 & 50.7 & 45.3 & 2040.1 \\
$1930 / 39$ & 70.5 & 91.7 & 100.9 & 128.0 & 204.1 & 133.5 & 97.7 & 87.5 & 73.9 & 73.4 & 74.9 & 70.0 & 1206.3 \\
$1940 / 49$ & 91.5 & 84.2 & 96.9 & 131.7 & 159.8 & 154.3 & 122.8 & 97.8 & 85.1 & 84.6 & 83.7 & 80.4 & 1272.9 \\
$1950 / 59$ & 68.5 & 82.1 & 111.5 & 131.8 & 138.7 & 137.6 & 92.4 & 63.6 & 49.3 & 48.5 & 51.6 & 53.3 & 1028.8 \\
$1960 / 69$ & 38.4 & 51.2 & 113.4 & 180.7 & 186.6 & 156.1 & 77.5 & 43.7 & 27.2 & 24.8 & 24.0 & 24.5 & 948.0 \\
$1970 / 79$ & 29.6 & 40.1 & 53.8 & 79.6 & 84.8 & 100.2 & 79.9 & 33.1 & 27.3 & 25.1 & 24.3 & 23.7 & 601.6 \\
$1980 / 89$ & 33.4 & 54.5 & 80.7 & 84.9 & 128.4 & 136.6 & 62.3 & 36.7 & 30.5 & 29.5 & 27.6 & 25.5 & 730.5 \\
$1990 / 95$ & 20.7 & 37.4 & 83.1 & 85.6 & 152.3 & 95.3 & 44.2 & 29.5 & 21.4 & 20.1 & 18.1 & 16.8 & 624.6 \\
\hline
\end{tabular}

Dead Sea Basin and for the Wadi Araba are not precise enough to fix inflow amounts since the rainfall is very low (less than $50 \mathrm{~mm} / \mathrm{y}$ ) and consequently surface water flows are so limited. However, they contribute less than $10 \%$ of the total inflow into the Dead Sea. Therefore, they induce a negligible error in the water balance equation. The dams on the side wadis capture most runoff waters and prevent this water to flow to the Dead Sea. The base flow was compiled by Abu-Qubu et al., (2016) from the MWI (2015) open files to reach $186.9 \times 106$ cubic meters, while it has been estimated as far as $197.3 \times 106$ cubic meters by (Margane et al., 2002).

The reality is that the surface runoff does not reflect the whole resource of that catchment, because there is an upstream withdrawal for different uses, i.e., irrigation and downstream inflow to dam reservoir. Furthermore, the groundwater table decline caused by excessive pumping which exceeds the groundwater safe yield of the different basins, which consequently reduced the base flow.

There would be an obvious influence of the Red Sea water upon the chemical characteristics of the mixed water ratios of the two different waters chemistry. As far as time precedes the salinity of the upper layer of the Dead Sea water will decrease continuously, thereafter, the amount and type of precipitated salts will be affected dramatically. The Dead Sea surface water level decline is a seasonal fluctuation component with reference to the direct amounts of rainfall and the related runoff waters. The monthly decline measurements taken by the authors are given in Table 2.

The readings for complete Arabic one year started in 12 Shaaban $1436 \mathrm{H}$ and ended in 12 Shaaban $1437 \mathrm{H}$ showed continuous decline in the Dead Sea water level integrated to $76.7 \mathrm{~cm}$. The data revealed that the water level is deeply influenced by the rainfall and runoff waters in addition the new-busted springs along the eastern shoreline of the Dead Sea, which discharge about $39.78 \times 106$ cubic meters per year of mostly brackish waters into the Dead Sea.

On the other hand, the obtained results of the Dead Sea water level measurements conducted by the APC (2016) showed non-reliable records. Through a personal communication (2016) with the staff, they said that these are in 
Table 2. The Dead Sea water level within the period 30 May 2015 up to 19 May 2016.

\begin{tabular}{ccccc}
\hline Date & Arabic Date & Decline cm & Period & Notes \\
\hline 02 Mar. 2015 & 12 Rajab 1436H & 00.0 & 00.0 & Datum \\
30 May 2015 & 12 Shaaban 1436H & 36.5 & 3 months & Dry \\
26 Sep. 2015 & 12 Dhu'l-Hijja 1436H & 43 & 7 months & Rain 15 Sep. \\
25 Oct. 2015 & 12 Muharram 1436H & 56.5 & 8 months & Raining \\
24 Nov. 2015 & 12 Safar 1437H & 34 & 9 months & Raining \\
24 Dec. 2015 & 12 Rabia I. 1437H & 37.5 & 10 months & Raining \\
22 Jan. 2016 & 12 Rabia II. 1437H & 46.8 & 11 months & Raining \\
21 Feb. 2016 & 12 Jamad I 1437H & 53.5 & 12 months & Dry \\
21 Mar. 2016 & 12 Jamad II 1437H & 67 & 13 months & Raining 13-17 \\
20 Apr. 2016 & 12 Rajab 1437H & 89 & 14 months & Raining 10-13 \\
19 May 2016 & 12 Shaaban 1437H & 113.2 & 15 months & Dry \\
\hline
\end{tabular}

general and estimations as far as they do not have any digital or non-digital gauges and they do not respectful records for any precise values. The unreliable estimated monthly records for the period between 2010 and 2015 of the Dead Sea water levels as registered by APC are as in Table 3.

In order to reach a desired new water level for the Dead Sea and then to stabilize it, we can calculate the needed amount of water that is to be supplied to its basin using the following formula:

$$
\Delta h=h d * v w / w d
$$

where, $\Delta h$ is the increase in water level, $h d$ is the deficit head of water, $v w$ is the water volume transferred by the canal and $w d$ is the water deficit in the balance equation. Considering the proposed scenario of providing an annual two billion cubic meters of the Red Sea waters to be drained into the Dead Sea by assuming the long term of Dead Sea surface decline of about $0.709 \mathrm{~m} / \mathrm{y}$. The calculated deficit in the water balance equation is 0.94 billion $\mathrm{m}^{3}$ (Abu-Qubu et al., 2016) which can be used to show that the raise in the Dead Sea water level will reach $0.709 \times 2 / 0.94=1.51 \mathrm{~m} / \mathrm{y}$. Therefore, it will take about 23 years to recover the desired level of $-395 \mathrm{~m}$.

\section{Mixing of Red Sea with Dead Sea Waters}

The main target of the Red/Dead Sea conveyance is to transfer a suitable water volume that can compensate the deficit of the water budget of the Dead Sea so forth, in order to stabilize the water level and stop its further decline without any possible environmental degradation. This scenario can be achieved by discharging about one billion cubic meters of Red Sea water into the Dead Sea Basin. The second scenario is to supply two billion cubic meters of Red Sea water to the Dead Sea Basin. In the second scenario, the high loss of Dead Sea water will be 
Table 3. The APC measurements for the Dead Sea water level 2010/2015 (Personal communication, 2016).

\begin{tabular}{ccccccc}
\hline Month & 2010 & 2011 & 2012 & 2013 & 2014 & 2015 \\
\hline & Level & Level & Level & Level & Level & Level \\
\hline Jan. & -423.190 & -424.240 & -425.604 & -426.760 & -427.910 & -428.90 \\
Feb. & -423.020 & -424.330 & -425.710 & -426.755 & -427.960 & -428.88 \\
Mar. & -423.100 & -424.360 & -425.825 & -426.815 & -427.970 & -428.89 \\
Apr. & -423.180 & -424.435 & NA & -426.910 & -428.070 & -428.96 \\
May & -423.270 & -424.540 & -425.990 & -426.990 & -428.040 & -429.02 \\
June & -423.360 & -424.670 & -426.126 & -427.103 & -428.110 & -429.12 \\
July & -423.500 & -424.790 & -426.282 & -427.330 & -428.400 & -429.32 \\
Aug. & -423.700 & -424.920 & -426.415 & -427.467 & -428.485 & -429.45 \\
Sep. & -423.780 & -425.045 & -426.560 & -427.568 & -428.590 & -429.51 \\
Oct. & -423.880 & -425.170 & -426.632 & -427.680 & -428.750 & -429.60 \\
Nov. & -424.030 & -425.300 & -426.750 & -427.760 & -428.800 & -429.66 \\
Dec. & -424.130 & -425.520 & -426.880 & -427.830 & -428.810 & -429.84 \\
Level difference & -0.94 & -1.28 & -1.28 & -1.07 & -0.90 & -0.94 \\
\hline & & & & & & \\
\hline
\end{tabular}

substituted and the water level of Dead Sea will be recovered to reach only the desired level of $-395 \mathrm{~m}$, which corresponds to the Dead Sea water level just before the main deep northern Dead Sea sub-basin was separated from the southern shallow Dead Sea sub-basin at the level of $(-400 \mathrm{~m})$ in 1976 (Steinhorn et al., 1979).

The above mentioned scenarios concerned the two billion cubic meters will lead to different changes in the hydrochemical characteristics of the Dead Sea. In this study, the probable mixing ratios as a function of time between Red/Dead Sea water according to the above scenarios will be delineated showing the composition of the Red/Dead Sea mixture taking into consideration the bathymetric survey of the Dead Sea.

\section{Dead Sea Surface Water Density}

The occurrence stratification on the upper mixed layer of the Dead Sea water is a result of the annual winter overturns due to the precipitated salt amounts from the upper mixed layer. Furthermore, the cut-off value of salinity, beyond which salinity cannot be increased as indicated by Gavrieli, \& Stein (2006). It has been established in previous stratification studies that the density of the upper body of the Dead Sea is strongly dependent on the rate of surface inflow. Complex mixing models have also been developed to simulate the mixing process in order to predict surface density.

For the Red/Dead Sea studies, the findings of Blasberger \& Elata (1983) are used to develop a relationship between historical surface density measurements 
and the derived surface inflows. This relationship is applied to the Dead Sea water balance model in order to reproduce the historical variation in surface density. The surface density variation predicted by the water balance model compares well with historical density measurements (Tahal, 2011).

The intensive evaporation rates cause a rapid gypsum formation, which turbid the Dead Sea water for a limited time before its settlement. Such a phenomenon was first observed by Bloch et al., (1944). Another whitening event was recorded in August 1959. Neev \& Emery (1967) observed a decrease in transparency of the upper Dead Sea layer from $3 \mathrm{~m}$ to less than $1 \mathrm{~m}$. The Whitening phenomenon leads to changes in the Dead Sea Basin physical characteristics, such as heat balance, and evaporation rate. This whitening phenomenon can be simulated experimentally in the laboratory. Whereas by increasing the concentration of the dissolved salts in the present Dead Sea water and by its evaporation up to two third of the original volume the gypsum started to form in suspension. This has been conducted in the laboratories of the University of Jordan/Dept. of Applied and Environmental Geology. The chemical analyses of the salts deposited on the successive declined levels of the Dead Sea on annual basis were done for eleven levels. This started from 2015 until 2004 (from the present shoreline upward). The obtained results are presented in Table 4.

The results reflected the possible environmental changes and the chemical variations of the Dead Sea constituents. It is noticed that the $\mathrm{P}_{2} \mathrm{O}_{5}$ wt $\%$ increased up to 0.98 while its lowest value was 0.04 . This is attributed to the blowing Khamaseen winds from the east, southeast and south during the annual early summer period, which bring phosphatic dust from the piled remnants of the manufactured Al Hasa phosphate deposits and from the Aqaba phosphogypsum piles. The phosphatic dust particles play as nuclei for the salts to be precipitated.

Table 4. The chemical analyses of salts deposited during 2004-2015 on the Dead Sea shorelines ( ${ }^{\star}$ SD1 corresponds to 2015 , SD2 to 2014 to SD11 to 2004)

\begin{tabular}{cccccccccccccc}
\hline $\mathrm{ID}^{*}$ & $\mathrm{Fe}_{2} \mathrm{O}_{3} \%$ & $\mathrm{MnO} \%$ & $\mathrm{TiO}_{2} \%$ & $\mathrm{CaO} \%$ & $\mathrm{~K}_{2} \mathrm{O} \%$ & $\mathrm{P}_{2} \mathrm{O}_{5} \%$ & $\mathrm{SiO}_{2} \%$ & $\mathrm{Al}_{2} \mathrm{O}_{3} \%$ & $\mathrm{MgO} \%$ & $\mathrm{Na} \%$ & $\mathrm{SO}_{3} \%$ & $\mathrm{Cl}_{\%}$ & $\mathrm{Total} \%$ \\
\hline $\mathrm{SD} 1$ & 0.09 & 0.003 & 0.002 & 1.30 & 0.04 & 0.22 & 0.03 & 0.03 & 0.52 & 34.0 & 1.20 & 53.25 & 90.68 \\
$\mathrm{SD} 2$ & 0.16 & 0.004 & 0.005 & 0.95 & 0.00 & 0.46 & 0.74 & 0.05 & 0.09 & 34.3 & 0.06 & 51.47 & 88.29 \\
$\mathrm{SD} 3$ & 0.14 & 0.004 & 0.007 & 1.38 & 0.00 & 0.26 & 0.74 & 0.06 & 0.00 & 36.9 & 0.15 & 58.57 & 98.21 \\
$\mathrm{SD} 4$ & 0.08 & 0.002 & 0.004 & 0.25 & 0.05 & 0.04 & 0.61 & 0.05 & 0.01 & 33.0 & 0.00 & 53.25 & 87.35 \\
$\mathrm{SD} 5$ & 0.09 & 0.003 & 0.007 & 0.46 & 0.00 & 0.13 & 0.24 & 0.02 & 0.00 & 35.0 & 0.00 & 53.25 & 89.2 \\
$\mathrm{SD} 6$ & 0.09 & 0.002 & 0.004 & 0.48 & 0.01 & 0.05 & 0.21 & 0.09 & 0.09 & 35.8 & 0.03 & 58.57 & 95.43 \\
$\mathrm{SD} 7$ & 0.17 & 0.005 & 0.020 & 0.93 & 0.007 & 0.05 & 1.39 & 0.15 & 0.05 & 37.0 & 0.00 & 58.57 & 98.34 \\
$\mathrm{SD} 8$ & 0.17 & 0.005 & 0.008 & 0.41 & 0.00 & 0.06 & 0.70 & 0.08 & 0.00 & 36.2 & 0.11 & 55.25 & 92.99 \\
$\mathrm{SD} 9$ & 0.09 & 0.002 & 0.003 & 0.65 & 0.00 & 0.22 & 0.12 & 0.02 & 0.00 & 35.0 & 0.33 & 55.25 & 91.68 \\
$\mathrm{SD} 10$ & 0.14 & 0.003 & 0.032 & 1.44 & 0.002 & 0.15 & 2.91 & 0.14 & 0.10 & 33.0 & 0.27 & 49.70 & 87.89 \\
$\mathrm{SD} 11$ & 0.23 & 0.010 & 0.030 & 3.25 & 0.020 & 0.98 & 2.58 & 0.28 & 0.12 & 35.0 & 2.50 & 55.25 & 100.25 \\
\hline
\end{tabular}


The complete absence of $\mathrm{SO}_{3}$ in the analyzed samples representing the years of 2009, 2011 and 2012 indicate an interruption of gypsum precipitation. This need more work in this aspect to emphasize the conditions responsible for the precipitation or interruption of gypsum and/or other minerals.

The comparisons of the percentage of $\mathrm{P}_{2} \mathrm{O}_{5}$ in the samples of the eleven successive past Dead Sea levels are represented in Figure 2.

To assure the role of the dust of phosphogypsum piles in the extreme southern part of Jordan and for comparison purposes, 12 phosphogypsum samples (AQ1 to AQ12) were collected and analyzed for their chemical constituents (Table 5). The presented results in Table 5 are the chemical analyses based on the (XRF) spectrometric analyses of lime and limestone according to ASTM C1271-12, LOI according to ASTM C25-11 section 19. It is clearly indicated that a good compatibility observed between the gained weight percent of $\mathrm{P}_{2} \mathrm{O}_{5}$ in both the salts of the past Dead Sea shoreline deposits listed in Table 4 and those of the
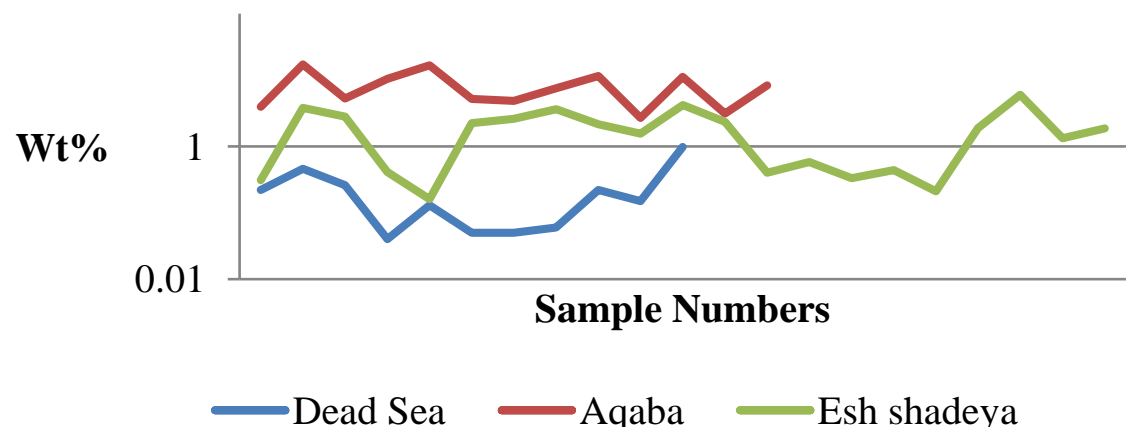

Figure 2. Comparison of $\mathrm{P}_{2} \mathrm{O}_{5} \%$ in salt deposits of Dead Sea shorelines with Aqaba and Esh-Shidiya Phosphate remnants.

Table 5. The XRF analyses of the phosphogypsum samples collected from Aqaba-Jordan.

\begin{tabular}{ccccccccccccc}
\hline ID & $\mathrm{Fe}_{2} \mathrm{O}_{3} \%$ & $\mathrm{TiO}_{2} \%$ & $\mathrm{CaO} \%$ & $\mathrm{~K}_{2} \mathrm{O} \%$ & $\mathrm{P}_{2} \mathrm{O}_{5} \%$ & $\mathrm{SiO}_{2} \%$ & $\mathrm{Al}_{2} \mathrm{O}_{3} \%$ & $\mathrm{MgO} \%$ & $\mathrm{Na}_{2} \mathrm{O} \%$ & $\mathrm{SO}_{3} \%$ & $\mathrm{~L} . \mathrm{O} . \mathrm{I} \%$ & $\mathrm{~T}$ otal \% \\
\hline AQ1 & 0.43 & 0.068 & 33.0 & 0.077 & 3.96 & 5.90 & 0.52 & 0.28 & 0.18 & 46.9 & 7.5 & 98.815 \\
$\mathrm{AQ} 2$ & 0.14 & 0.013 & 18.5 & 0.040 & 17.20 & 2.90 & 0.14 & 0.25 & 0.82 & 22.6 & 35.5 & 98.103 \\
$\mathrm{AQ3}$ & 0.17 & 0.021 & 34.0 & 0.009 & 5.28 & 3.91 & 0.14 & 0.17 & 0.12 & 46.8 & 8.8 & 99.420 \\
AQ4 & 0.20 & 0.023 & 28.0 & 0.033 & 10.40 & 3.79 & 0.16 & 0.22 & 0.48 & 36.6 & 19.6 & 99.506 \\
AQ5 & 0.25 & 0.019 & 20.7 & 0.022 & 16.71 & 2.47 & 0.64 & 0.33 & 0.37 & 30.6 & 27.9 & 100.011 \\
AQ6 & 0.18 & 0.025 & 30.7 & 0.010 & 5.18 & 7.79 & 0.31 & 0.22 & 0.05 & 43.2 & 12.3 & 99.965 \\
AQ7 & 0.17 & 0.025 & 31.3 & 0.005 & 4.83 & 7.97 & 0.23 & 0.18 & 0.05 & 44.3 & 9.7 & 98.760 \\
AQ8 & 0.21 & 0.024 & 29.8 & 0.010 & 7.54 & 6.19 & 0.26 & 0.22 & 0.16 & 42.8 & 11.6 & 98.814 \\
AQ9 & 0.39 & 0.023 & 26.8 & 0.025 & 11.5 & 5.70 & 0.36 & 0.28 & 0.10 & 36.8 & 17.8 & 99.778 \\
AQ10 & 0.29 & 0.037 & 32.9 & 0.038 & 2.68 & 7.73 & 0.56 & 0.27 & 0.20 & 47.0 & 7.0 & 98.705 \\
AQ11 & 0.27 & 0.023 & 22.8 & 0.031 & 11.2 & 3.30 & 0.64 & 0.34 & 0.30 & 32.3 & 29.0 & 100.204 \\
AQ12 & 0.17 & 0.023 & 34.1 & 0.003 & 3.11 & 5.50 & 0.23 & 0.15 & 0.11 & 48.4 & 6.8 & 98.596 \\
Average & 0.24 & 0.03 & 28.55 & 0.03 & 8.30 & 5.26 & 0.35 & 0.24 & 0.25 & 39.86 & 16.13 & \\
\hline
\end{tabular}


phosphogypsum deposits. It is obvious that the $\mathrm{P}_{2} \mathrm{O}_{5}$ percentage is varying as a time function, where it depends on the blowing Khamaseen summer winds. The Khamaseen wind probably responsible factor controlling the transported amounts of phosphogypsum from Aqaba area in the extreme south of Jordan and from Esh-Shidiya phosphate pile in the south eastern part of Jordan toward the Dead Sea and it vicinity.

The chemical analyses of salts deposited mentioned in Table 5 compares the chemical analyses of the Dead Sea waters for the same period given by APC laboratories presented in Table 6. It is clearly indicating that the absence of orthophosphate in the analyses mentioned in Table 6 prove the role of phosphate dust particles in the salt deposits at the shorelines of the Dead Sea. The phosphate particles play a catalyzing agent in the above-mentioned salt deposits.

Furthermore, the analyses of the samples collected from the disposal remnants of phosphate piles in Esh-Shidiya and Hasa area located in the southeastern part of Jordan are given in Table 7. Similarly, the $\mathrm{P}_{2} \mathrm{O}_{5}$ percentages are compatible with the results of the chemical analyses of the past water levels of the Dead Sea.

Actually in this study, two scenarios were experimentally implemented, the first scenario nominated to be zero scenario whereas no water source is conveyed to the Dead Sea and in this case the Dead Sea water is left to be evaporated continuously. In the zero scenario the Dead Sea water level will be declined continuously with time by an average of $0.71 \mathrm{~m}$ per year corresponding to the to the long term average and might reach up to $76.7 \mathrm{~cm}$ as measured in Table 2 for May 2015 to May 2016, but could reach one meter per year regarding the APC measurements in last ten years.

The historical analyses of the Dead Sea water chemical components are collected from different sources are listed in Table 8. It is quite obvious that the sodium ions are still in the same range since the halite recently started to precipitate, i.e., after 1983 according to Steinhorn (1979). In the same context, the authors indicated that the Ca still occasionally form carbonate minerals, therefore

Table 6. APC Dead Sea water chemical analyses for the period 2010 to 2015 (personal communication).

\begin{tabular}{cccccccc}
\hline \multirow{2}{*}{ Year } & Temp. & Density & $\mathrm{Mg}$ & $\mathrm{Ca}$ & $\mathrm{K}$ & $\mathrm{Na}$ & $\mathrm{Cl}$ \\
\cline { 2 - 7 } & ${ }^{\circ} \mathrm{C}$ & $\mathrm{g} / \mathrm{cm}^{3}$ & $\mathrm{~g} / \mathrm{L}$ & $\mathrm{g} / \mathrm{L}$ & $\mathrm{g} / \mathrm{L}$ & $\mathrm{g} / \mathrm{L}$ & $\mathrm{g} / \mathrm{L}$ \\
\hline 2010 & 29.6 & 1.24 & 49.972 & 18.6 & 8.308 & 31.124 & 234.36 \\
2011 & 28.73 & 1.24 & 49.476 & 18.104 & 8.308 & 30.752 & 231.508 \\
2012 & 28.99 & 1.24 & 50.468 & 18.228 & 8.308 & 30.504 & 234.112 \\
2013 & 29.06 & 1.24 & 50.84 & 18.228 & 8.184 & 30.008 & 234.236 \\
2014 & 29.6 & 1.24 & 51.336 & 18.228 & 8.308 & 29.388 & 234.98 \\
2015 & 30.5 & 1.24 & 52.7 & 19.468 & 8.308 & 27.9 & 238.576 \\
\hline
\end{tabular}


Table 7. The XRF analyses of phosphate disposal piles in Esh-Shedya area (Southeast Jordan).

\begin{tabular}{|c|c|c|c|c|c|c|c|c|c|}
\hline Id. & $\mathrm{Fe}_{2} \mathrm{O}_{3} \%$ & $\mathrm{TiO}_{2} \%$ & $\mathrm{CaO} \%$ & $\mathrm{~K}_{2} \mathrm{O} \%$ & $\mathrm{P}_{2} \mathrm{O}_{5} \%$ & $\mathrm{SiO}_{2} \%$ & $\mathrm{Al}_{2} \mathrm{O}_{3} \%$ & $\mathrm{MgO} \%$ & L.O.I \% \\
\hline HS1 & 0.16 & 0.012 & 54.00 & 0.000 & 0.31 & 3.10 & 0.31 & 0.22 & 41.5 \\
\hline HS2 & 1.35 & 0.170 & 33.50 & 0.080 & 3.79 & 29.90 & 3.28 & 1.13 & 26.0 \\
\hline HS3 & 1.38 & 0.186 & 29.70 & 0.153 & 2.81 & 36.90 & 2.84 & 2.73 & 22.0 \\
\hline HS4 & 1.11 & 0.187 & 32.80 & 0.142 & 0.41 & 33.20 & 1.72 & 1.94 & 28.1 \\
\hline HS5 & 0.48 & 0.045 & 49.90 & 0.035 & 0.16 & 6.89 & 0.88 & 0.74 & 40.6 \\
\hline HS6 & 1.22 & 0.160 & 42.70 & 0.027 & 2.23 & 15.70 & 3.09 & 0.90 & 32.7 \\
\hline HS7 & 1.45 & 0.180 & 41.33 & 0.380 & 2.61 & 15.45 & 4.07 & 0.79 & 32.3 \\
\hline HS8 & 1.49 & 0.170 & 34.19 & 0.250 & 3.62 & 28.11 & 3.64 & 0.90 & 25.9 \\
\hline HS9 & 0.61 & 0.050 & 47.21 & 0.020 & 2.15 & 11.89 & 1.02 & 0.53 & 35.8 \\
\hline HS10 & 1.42 & 0.190 & 41.30 & 0.240 & 1.56 & 15.52 & 4.31 & 0.63 & 33.2 \\
\hline HS11 & 0.51 & 0.040 & 42.59 & 0.037 & 4.19 & 12.83 & 0.85 & 3.88 & 33.6 \\
\hline HS12 & 0.18 & 0.005 & 33.90 & 0.000 & 2.34 & 1.13 & 0.08 & 18.10 & 42.8 \\
\hline HS13 & 0.17 & 0.007 & 35.00 & 0.000 & 0.40 & 0.90 & 0.11 & 17.12 & 44.9 \\
\hline HS14 & 0.90 & 0.137 & 31.60 & 0.120 & 0.58 & 38.30 & 1.26 & 1.31 & 25.5 \\
\hline HS15 & 0.60 & 0.059 & 46.80 & 0.022 & 0.33 & 12.90 & 0.87 & 0.96 & 37.2 \\
\hline HS16 & 1.40 & 0.163 & 31.50 & 0.218 & 0.44 & 36.40 & 1.81 & 1.09 & 26.6 \\
\hline HS17 & 0.24 & 0.025 & 49.70 & 0.012 & 0.21 & 10.80 & 0.50 & 0.004 & 38.3 \\
\hline HS18 & 1.20 & 0.092 & 32.80 & 0.074 & 1.90 & 9.09 & 1.70 & 12.97 & 39.9 \\
\hline HS19 & 0.61 & 0.051 & 43.50 & 0.038 & 5.99 & 16.80 & 1.09 & 0.72 & 30.5 \\
\hline HS20 & 1.50 & 0.141 & 40.20 & 0.285 & 1.33 & 18.10 & 2.64 & 0.77 & 33.9 \\
\hline Average & 0.90 & 0.10 & 39.71 & 0.11 & 1.87 & 17.70 & 1.80 & 3.37 & 33.57 \\
\hline
\end{tabular}

Table 8. The Dead Sea water chemical constituents at different dates (g/L).

\begin{tabular}{cccccccccc}
\hline Reference & $\mathrm{Na}$ & $\mathrm{K}$ & $\mathrm{Ca}$ & $\mathrm{Mg}$ & $\mathrm{Cl}$ & $\mathrm{Br}$ & $\mathrm{HCO}_{3}$ & $\mathrm{SO}_{4}$ & $\mathrm{TDS}$ \\
\hline Bentor 1961 & 33.5 & 6.3 & 13.0 & 34.5 & 180.0 & 4.1 & 0.248 & 0.9 & 242.8 \\
Gravieli 2003 & 34.3 & 8.0 & 18.3 & 47.1 & 228.6 & 5.4 & 0.3 & 0.4 & 342.4 \\
APC 2015 & 27.9 & 8.3 & 19.5 & 52.7 & 238.6 & 5.6 & 0.25 & 0.3 & 349.1 \\
Auth (MEMR) & 33.75 & 9.12 & 21.22 & 49.4 & & & & & \\
\hline
\end{tabular}

its concentration is clearly continuing to increase. This fact later on will cause the turbid of the Dead Sea water after certain level of decline as far as the now evaporation rates are continued without any new supply of additional inflows to the Dead Sea Basin. The magnesium concentration is also increasing as a result of high rates of evaporation and no carbons are formed especially dolomites. The potassium, shows an increasing concentration even the large amounts of potash industries, this is can be referred to the intensive evaporation rates. Chloride and bromide are showing an increased concentration which can be attributed to the 
same reasons as well.

The chemical constituents of the present Dead Sea water and in the past before starting the intensive evaporation process and after dropping down the transferred water from the Dead Sea catchment are presented in (Table 8). It is clear that the gypsum precipitation cause a recognized decrease of the $\mathrm{SO}_{4}$ ions in the Dead Sea water, in the same context, Na cations decrease significantly as a result of halite precipitation. The Ca concentration increased as far as the evaporation is very high, and the formation of carbonates still low. The Dead Sea water still un saturated with reference to the dissolvent such as $\mathrm{Mg}, \mathrm{K}, \mathrm{Br}$, and many others. But the slow increments in the minor constituents such as $\mathrm{K}, \mathrm{Br}$ and $\mathrm{Mg}$ are generally attributed to the intensive evaporation rates. On the other hand, the authors believe that the new busted springs along the Dead Sea declined shorelines cause the advance of the interface between the Dead Sea and the juxtapose aquifer systems toward the Dead Sea basin. This process is evaluated to bring about $39 \times 106$ cubic meters of recovered brine and saline waters which increase the ratios of different element in the last year, such as $\mathrm{Na}, \mathrm{Ca}, \mathrm{Br}$, and other minor elements.

The laboratory experimental work applied to simulate the different precipitated salts at different evaporation levels assuming the first scenario of zero Red Sea water conduits to the Dead Sea. The second group of experiments was used to simulate the expected transferred two billion cubic meters of Red Sea water rates with respect to the available water in the Dead Sea. In one of the experiments a volume of 2.5 liters of Dead Sea water were used in this experiment. Hence, one liter of the water was evaporated to represents $40 \%$ of its original volume and the precipitate was analyzed. Consequently, similar experiment was conducted to evaporate two liters to represents $80 \%$ of the original volume. The major chemical constituents of the precipitate from the above two experiment are presented in Table 9. At the beginning, Gypsum was precipitating until the percentage of evaporation reach about $40 \%$ where, Halite started to precipitate, and at late stages where evaporation reached to about $80 \%$ the $\mathrm{MgCl}_{2}$ started to form most probably Bischofite minerals. Bischofite is a hydrous magnesium chloride mineral believed to precipitate at $80 \%$ evaporation of the Dead Sea water. Bischofite has the chemical formula of $\mathrm{MgCl}_{2} \cdot 6 \mathrm{H}_{2} \mathrm{O}$. The magnesium chloride forms up to $350 \mathrm{~g} / \mathrm{L}$ of Bischofite, and it contains about 70 elements as impurities as $\mathrm{K}, \mathrm{Na}, \mathrm{Br}, \mathrm{B}, \mathrm{Ca}, \mathrm{Si}, \mathrm{Mo}, \mathrm{Ag}, \mathrm{Zn}, \mathrm{Fe}$, and $\mathrm{Cu}$.

Sulfate contents suggest that $40 \%$ of the Dead Sea water was evaporated since 1950s until 2015. The chemical composition of the Red Sea water is shown in

Table 9. The analyses of precipitate from $40 \%$ and $80 \%$ evaporation of Dead Sea water (g/L).

\begin{tabular}{ccccccccccc}
\hline Evaporation level & $\mathrm{Na}$ & $\mathrm{K}$ & $\mathrm{Ca}$ & $\mathrm{Mg}$ & $\mathrm{Cl}$ & $\mathrm{Br}$ & $\mathrm{F}$ & $\mathrm{Si}$ & $\mathrm{S}$ & $\mathrm{P}$ \\
\hline $40 \%$ & 213.3 & 122.5 & 54.6 & 116.6 & 709.3 & 14.3 & 2.1 & 1.5 & 2.8 & 0.864 \\
$80 \%$ & 2.8 & 4.1 & 32.4 & 257.9 & 905.2 & 55.8 & 0 & 1.3 & 1.7 & 0.69192 \\
\hline
\end{tabular}


Table 10. This table shows the present and the historical constituents of the Red Sea for comparison purposes. It is clear that the $\mathrm{SO}_{4}$ contents are very high with respect to that of the Dead Sea. Therefore, it is expected to accelerate the precipitation of gypsum during the advanced mixing times where the ratio increases up to $1: 1$ ratio.

The average contents percentages of major ions constituent of the return brine water rejected into the Dead Sea by the APC are given in Table 11 . These chemical analyses are a good indicator for the changes that take place after the extraction of potash.

Consequently, it is observed the difference in the anions and cations dissolved in each of the Red Sea and Dead Sea water bodies. The important amounts of deposits from the Dead Sea water are the halite and gypsum. These two salts are mainly expected to be influenced by the introduced Red Sea water, where it contains higher sulfate contents than the Dead Sea water, while the Dead Sea have more calcium contents. This situation leads to increase the formation of gypsum deposits and consequently reduce the precipitated amount of the halite mineral. In this context, the experiments for this scenario carried out on the Dead Sea water without the intrusion of the Red Sea water. In this case, the Dead Sea water will be the most deteriorated situation whereas, the intensive lack in the water balance equation will continue at the same present rates and consequently the results revealed that at a certain level of the concentrated saline water the gypsum crystals will be stared to form and some of them continue to be suspended in the solution.

Table 10. The chemical composition (mg/L) of the Red Sea water (2016) compared with (2002).

\begin{tabular}{cccccccccc}
\hline Ref. & $\mathrm{Na}$ & $\mathrm{K}$ & $\mathrm{Ca}$ & $\mathrm{Mg}$ & $\mathrm{Cl}$ & $\mathrm{Br}$ & $\mathrm{SO}_{4}$ & $\mathrm{TDS}$ & Area \\
\hline Miller 1965 & 88.0 & 0.300 & 5.4 & 0.8 & 163.0 & 0.07 & 1.0 & & \\
Peter 1969 & 92.6 & 0.187 & 5.15 & 0.764 & 156.03 & 0.128 & 0.84 & & \\
Abdel-Aal 2015 (mg/L) & 123.39 & 0.287 & 738 & 1570 & 23,607 & & 1260 & 42.07 & Egypt \\
Lenntech (mg/L) & 142.55 & 0.210 & 225 & 742 & 22,219 & 72 & 3078 & 41.00 Jeddah \\
\hline
\end{tabular}

Table 11. The APC chemical analyses show the average contents percent of the return water.

\begin{tabular}{ccccccccccc}
\hline \multirow{2}{*}{ Year } & TEMP & DENS & ACTUAL & $\mathrm{Mg}$ & $\mathrm{Ca}$ & $\mathrm{K}$ & $\mathrm{Na}$ & $\mathrm{Cl}$ & $\mathrm{H}_{2} \mathrm{O}$ & $\mathrm{Mg}+\mathrm{Ca}$ \\
\cline { 2 - 9 } & $\left(\mathrm{C}^{\prime}\right)$ & at 36C' & $\begin{array}{c}\text { Density } \\
\text { gm/cm }\end{array}$ & $\%$ & $\%$ & $\%$ & $\%$ & $\%$ & $\%$ & $\%$ \\
\hline 2010 & 29.41 & 1.24 & 1.24 & 4.10 & 1.49 & 0.67 & 2.42 & 18.92 & 72.41 & 5.59 \\
2011 & 29.41 & 1.24 & 1.24 & 4.10 & 1.49 & 0.67 & 2.42 & 18.92 & 72.41 & 5.59 \\
2012 & 29.39 & 1.24 & 1.24 & 4.11 & 1.49 & 0.67 & 2.40 & 18.92 & 72.41 & 5.60 \\
2013 & 29.48 & 1.24 & 1.24 & 4.12 & 1.49 & 0.67 & 2.39 & 18.96 & 72.36 & 5.62 \\
2014 & 29.55 & 1.24 & 1.24 & 4.13 & 1.50 & 0.67 & 2.38 & 18.97 & 72.35 & 5.63 \\
2015 & 29.4 & 1.24 & 1.24 & 4.11 & 1.49 & 0.67 & 2.40 & 18.94 & 72.39 & 5.60 \\
\hline
\end{tabular}


But, at an advanced level of declined surface water in the basin of the saline Dead Sea water will suddenly form a floating layer of the precipitated salts with a less density than the captures water on the bottom of the basin. Thus, this floating layer of the precipitate will make a barrier prevent the evaporation of the captured waters. After certain thickening of the formed salt layer stalactites are started to form.

The second scenario represents the annual mixing of two billion cubic meters of the Red Sea water with the estimated 150 billion cubic meter of the Dead Sea water in the year 2015. Mixing is suggested to take place continuously, therefore, an experimental work was developed for different times at certain ratios as shown in Table 12 and in Figure 3.

Table 12. Chemical analyses of different stages of mixing the Red/Dead Sea waters.

\begin{tabular}{ccccc}
\hline Ratio X:150 & $\mathrm{Ca}(\mathrm{g} / \mathrm{L})$ & $\mathrm{Mg}(\mathrm{g} / \mathrm{L})$ & $\mathrm{K}(\mathrm{g} / \mathrm{L})$ & $\mathrm{Na}(\mathrm{g} / \mathrm{L})$ \\
\hline 0 & 21.22 & 49.4 & 9.120 & 33.75 \\
2 & 21.02 & 48.78 & 8.92 & 32.75 \\
4 & 20.92 & 46.16 & 8.73 & 31.81 \\
6 & 20.71 & 44.56 & 8.53 & 30.81 \\
8 & 20.48 & 44.12 & 8.52 & 30.75 \\
10 & 20.36 & 43.84 & 8.52 & 30.69 \\
14 & 18.82 & 43.32 & 8.50 & 30.56 \\
15 & 18.22 & 42.23 & 8.50 & 30.53 \\
20 & 17.42 & 41.64 & 8.48 & 30.38 \\
30 & 16.40 & 39.89 & 8.44 & 30.07 \\
70 & 15.92 & 34.51 & 6.01 & 28.33 \\
75 & 13.63 & 33.84 & 6.18 & 28.10 \\
100 & 15.57 & 31.59 & 5.74 & 27.18 \\
150 & 11.04 & 27.09 & 4.854 & 25.11 \\
225 & 9.47 & 23.03 & 4.075 & 23.36 \\
300 & 7.53 & 18.86 & 3.242 & 21.71 \\
\hline
\end{tabular}

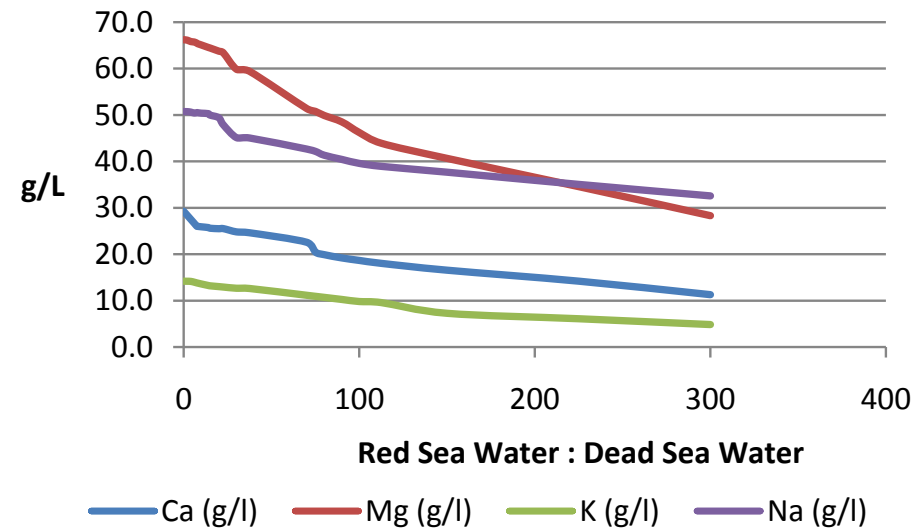

Figure 3. Changes of different ions by mixing Red Sea waters with the Dead Sea waters. 


\section{Conclusion}

The current investigation revealed that mixing occurs until certain depth and no mixing advances below this plane, this divider plane that separates between two distinguished salinities is called Barzasch Plane. In the case of the Dead Sea water with the Red Sea water, the Barzasch plane is found to be at $22 \%-24 \%$ of the column length of the Dead Sea water. The depth of Barzasch plane is found to be a function of salinities rather than the mixed amounts of the two different water bodies.

\section{Conflicts of Interest}

The authors declare no conflicts of interest regarding the publication of this paper.

\section{References}

Abu-Qubu, J., Merkel, B., Dunger, V., Rimawi, O., \& Abu-Hamatteh, Z. S. H. (2016). Impact of Mineral Precipitation On the Dead Sea Water Level Descends. International Journals of Engineering \& Scientific Research, 4, 40-51.

Arab Potash Company (APC) (2016). Personal Written Communications.

Blasberger, A., \& Elata, C. (1983). Hydrodynamic Model for the Dead Sea: Summary Report for the 3rd Year. Mechanical Engineering Department, Ben Gurion University, $61 \mathrm{p}$.

Bloch, R., Littman, H. Z., \& Elazari-Volcani, B. (1944). Occasional Whiteness of the Dead Sea. Nature, 154, 402-403. https://doi.org/10.1038/154402a0

Gavrieli, I., \& Stein, M. (2006). On the Origin and Fate of Brines in the Dead Sea Basin. Special Papers of the Geological Society of America, 401, 183-194. https://doi.org/10.1130/2006.2401(12)

Khlaifat, A., Batarseh, M., Nawayseh, K., Amira, J., \& Talafeha, E. (2020). Mixing of Dead Sea and Red Sea Waters and Changes in Their Physical Properties. Heliyon, 6, e05444. https://doi.org/10.1016/j.heliyon.2020.e05444

Margane, A., Manfred, H., Almomani M., \& Subah A. (2002). Contribution to the Hydrogeology of North and Central Jordan-Geologisches Jahrbuch Reihe C, B and C 68. Schweizerbart Science Publishers, $52 \mathrm{p}$.

Meteorological Department (2002). Jordan Climatological Handbook.

Ministry of Water and Irrigation (MWI) (2013-2015). Open Files.

Neev, D., \& Emery, K. O. (1967). The Dead Sea. Depositional Processes and Environments of Evaporites. State of Israel, Ministry of Development, Geological Survey, 147 p.

Reiss, A. G., Ganor, J., Hamawi, M., \& Gavrieli, I. (2021). Dynamics of Turbidity in Gypsum-Precipitating Brines: The Case of the Red Sea-Dead Sea Project. Journal of Environmental Management, 288, Article ID: 112369.

https://doi.org/10.1016/j.jenvman.2021.112369

Steinhorn, I., Assaf, G., Gat, J. R., Nishri, A., Nissenbaum, A., Stiller, M., Beyth, M., Neev, D., Graber, R., Friedman, G. M., \& Weiss, W. (1979). The Dead Sea: Deepening of the Mixolimnion Signifies the Overturn of the Water Column. Science, 206, 55-57. https://doi.org/10.1126/science.206.4414.55

TAHAL Group (2011). Red Sea-Dead Sea Water Conveyance Study Program, Dead Sea Study. Final Report, GSI Report Number: GSI/10/2011. 
The World Bank (2009). World Bank Group Statement on Red Sea-Dead Sea Water Conveyance Study Program.

Water Authority of Jordan (WAJ) (1922-2014). Meteorological Department Open Files. 